\title{
Sexual Desire and Structural Injustice
}

\section{Tom O’Shea}

\section{Forthcoming at the Journal of Social Philosophy}

Is it unjust that some people are less sexually desired than others? We might have sympathy for the sexually undesired but supposing they suffer an outright injustice can seem absurd. My view is that this reaction is too hasty, and that sexually desirability can be a matter of political justice. This is a strong claim, which is likely to invite a torrent of objections, whether for confusing misfortune with injustice, licensing unwarranted political meddling, indulging in sexual moralism, or asking the impossible of us. But I shall suggest a compelling social philosophy of sexual attraction can be articulated by considering the scope and character of sexual desires through the lens of structural injustice, while looking to collective and political rather than primarily individual and ethical remedies to the problem of unjust desire.

Sexual desirability is not a resource which can or should be doled out to the needy; nor is there a duty to desire, or a right to be so desired. Yet, sexual attractiveness matters in many of our lives - potentially influencing not only our opportunities for sexual intimacy, but our self-respect, social standing, and access to romantic relationships. Going sexually undesired or under-desired can compound disadvantage in these respects. Mere disadvantage, however, is not sufficient for political injustice. Instead, I shall argue there can be grounds of justice for holding people responsible for transforming the socio-structural processes which shape the distribution and character of sexual desires when these processes underpin domination and deprivation. 
When, in 1854, John Stuart Mill suspected he was dying of tuberculosis, he took to his diary. His entry for March $26^{\text {th }}$ tells us, "what any persons may freely do with respect to sexual relations should be deemed to be an unimportant and purely private matter, which concerns no one but themselves."1 This may have been a particularly alluring proposition for Mill himself, who had courted scandal with an initially chaste but deeply intimate friendship with the married Harriet Taylor. His maxim is no more than a sketch, but it helpfully anticipates and condenses many contemporary liberal orthodoxies about sex - acting as an appealing corrective to prudish moralism and supposing that consensual sexual activity should not draw social opprobrium. But like many appealing maxims, it happens to be false.

Some recent philosophical discussions of sexual attraction begin to put pressure on Mill's claim that freely undertaken sexual relations are unimportant, purely private, and of no concern to others. The most common counterexample has been racial preference in online dating. Armed with statistics from dating sites like OkCupid, philosophers have noted with regret that in some places black women and Asian men are systematically passed over by other daters. $^{2}$ Dating preferences depend upon more than sexual attraction, of course, but if these preferences are sustained by sexual desires which reflect and reproduce disrespectful attitudes towards certain racial groups, then there are grounds for moral concern. Sonu Bedi goes further

\footnotetext{
${ }^{1}$ John Stuart Mill, Collected Works of John Stuart Mill, vol. 26-27, ed. John Robson, (London: Routledge, 1988), p. 664.

2 Sonu Bedi, 'Sexual Racism: Intimacy as a Matter of Justice', The Journal of Politics 77:4 (2015), pp. 998-1011, p. 998; Megan Mitchell and Mark Wells, 'Race, Romantic Attraction, and Dating', Ethical Theory and Moral Practice 21:4 (2018), pp. 945-61, p. 956; Hugh Lazenby and Paul Butterfield, 'Discrimination and the Personal Sphere', The Routledge Handbook of the Ethics of Discrimination, ed. Kasper Lippert-Rasmussen (Abingdon: Routledge, 2018), pp. 369-378, p. 369. The relevant data were reported at OkCupid, 'Race and Attraction, 20092014', The OkCupid Blog, available: https://theblog.okcupid.com/race-and-attraction-2009-2014-107dcbb4f060 [accessed August 2019].
} 
still when he argues that if people are deprived of sexual intimacy on grounds of their race, then subject to certain provisos, this is more than "a private or moral wrong but an issue of social justice". ${ }^{3}$ In support of this conclusion, he tries to show that the opportunity for sexual intimacy is a distinct primary good which almost all people pursue at some time in their lives, as well as being a contributor to the social bases of self-respect, and a central capability underpinning human dignity.

Nor is racialised sexual aversion the only ground for concern. Robin Zheng argues that the fetishization of Asian women - known as 'yellow fever' - not only compounds racial othering, but can also lead its targets to experience a harmful depersonalisation. ${ }^{4}$ These women often struggle with the suspicion that they are not desired as individuals but merely as placeholders for some fantasy of submissive or exotic Asian femininity. Racialised fetishes are cases of sexual fixation rather than aversion, which raise concerns about the character and scope of sexual desire rather than its absence. Likewise, Russell Robinson has queried the racial dynamics of some gay communities, where "men of color face pressure to conform to certain racialized sex roles, such as the 'aggressive black top' and the 'submissive Asian bottom.",

We also find similar depersonalisation, objectification, and stereotyping to those identified by Zheng and Robinson independently of racial preferences, such as in the experiences of transgender and overweight people who are fetishised by 'chasers' ${ }^{6}$ So too,

\footnotetext{
${ }^{3}$ Bedi, 'Sexual Racism', p. 998.

${ }^{4}$ Robin Zheng, 'Why Yellow Fever Isn't Flattering: A Case Against Racial Fetishes', Journal of the American Philosophical Association 2:3 (2016), pp. 400-19. See also the discussion of fungibility in Martha Nussbaum, 'Objectification', Philosophy \& Public Affairs 24 (1995), pp. 249-91, p. 257.

${ }^{5}$ Russell Robinson, ‘Structural Dimensions of Romantic Preferences', Fordham Law Review 76 (2008), pp. 2787 819 , p. 2788.

${ }^{6}$ See Goda Klumbyte and Katrine Smiet, 'Bodies Like Our Own? The Dynamics of Distance and Closeness in Online Fat Porn', Fat Sex: New Directions in Theory and Activism, Helen Hester and Caroline Walters (Farnham: Ashgate, 2015), pp. 133-54, pp. 145-6; Juno Dawson, “'I Can’t Be A 24-Hour Sexual Fantasy”: Juno Dawson on
} 
Elizabeth Emens claims the infantalisation and wider desexualisation of those with disabilities often exposes them to what she calls "intimate discrimination". ${ }^{7}$ Legal and cultural norms which reinforce the assumption that people with disabilities are primarily nonsexual - or alternatively, so hypersexual that they cannot responsibly exercise sexual autonomy contribute to a social environment that excludes them from sexual relationships. ${ }^{8}$

These are all candidates for what I call 'orectic injustice': a form of injustice which arises from the distribution or character of people's desires. I do not claim that every one of these cases is an injustice, but will defend the more general claim that there are some sexual orectic injustices which we can have responsibilities to address. I begin negatively by raising further objections to identifying unjust patterns of sexual desire. Then, I develop a positive account of orectic justice grounded in a model of structural injustice and political responsibility, which is equipped to answer these concerns.

We can start with some folk wisdom from a song by the pop singer Selena Gomez. Her track “The Heart Wants What It Wants" echoes a line from one of Emily Dickinson's letters in order to describe the dynamics of a troubled romantic relationship. ${ }^{9}$ In the chorus, Gomez sings, “There's a million reasons why I should give you up / But the heart wants what it wants." The song is premised on a platitude - namely, that we do not get to decide who we are sexually or romantically attracted to. We cannot simply opt in or out of erotic attraction, even if this

Dating as a Trans Woman', The Guardian (Friday 19 th $^{\text {May }}$ 2017), available: https://www.theguardian.com/society/2017/may/19/juno-dawson-cant-be-24-hour-sexual-fantasy-dating-transwoman [accessed: August 2019].

${ }^{7}$ Elizabeth Emens, 'Intimate Discrimination: The State's Role in the Accidents of Sex and Love', Harvard Law Review 122:1307 (2009), pp. 1308-1402.

${ }^{8}$ Emens, 'Intimate Discrimination', p. 1325.

${ }^{9}$ Selena Gomez, 'The Heart Wants What It Wants', For You (Hollywood Records, 2014); Emily Dickinson, The Letters of Emily Dickinson, vol 2, eds. Thomas Johnson and Theodora Ward (Cambridge, MA: Harvard University Press, 1958), p. 405. 
attraction is bad for ourselves or others. If this is true, then it might seem pointless to criticise or evaluate our sexual and romantic desires: they control us, and not the other way around.

If we cannot choose our desires, then it might seem like we have no ability to desire otherwise than we do, and therefore no duty of justice to do so. Of course, in this form, the objection is weak. While it is true that we do not simply choose our sexual desires, Mitchell and Wells appeal to an analogy with culinary desires to show how we can have some control over their formation. ${ }^{10}$ We cannot simply choose to like mushrooms in the way that we can simply select a mushroom dish from a menu. Yet, we can sometimes habituate our desires learning to want different things through exposure to them, such as by developing new sexual desires by socialising with a broader range of people. Likewise, Ann Cahill compares sexual desire to laughter, which can be experienced as involuntary in the moment, without this precluding the project of developing a less racist, sexist, or ableist sense of humour. On the basis of this analogy, Cahill suggests that sexual desires can also be reformed - recommending both self-reflection and an attempt to weaken ingrained habits through placing oneself in a new social environment as imperfect but worthwhile routes to achieving this. ${ }^{11}$ Of course, the plasticity of sexual desire can have its limits (think of the harmful and typically unsuccessful practice of gay and lesbian conversion therapy) but Mitchell, Wells, and Cahill all plausibly propose that sometimes we are able change some of the conditions under which our sexual desires are generated. ${ }^{12}$

\footnotetext{
${ }^{10}$ Mitchell and Wells, 'Race, Romantic Attraction, and Dating', p. 950.

${ }^{11}$ Ann J. Cahill, 'Sexual Desire, Inequality, and the Possibility of Transformation', Body Aesthetics, ed. Sherri Irvin (Oxford: Oxford University Press, 2016), pp. 281-98, p. 293f.

${ }^{12}$ Douglas Haldeman, 'The Practice and Ethics of Sexual Orientation Conversion Therapy', Journal of Consulting and Clinical Psychology 62:2 (1994), pp. 221-227.
} 
Yet, should we do so? Andera Long Chu expresses scepticism about the selfdisciplining of desire. She tells us:

nothing good comes of forcing desire to conform to political principle. You could sooner give a cat a bath. [...] Desire is, by nature, childlike and chary of government. The day we begin to qualify it by the righteousness of its political content is the day we begin to prescribe some desires and prohibit others. That way lies moralism only. ${ }^{13}$

We find a number of concerns hinted at here: from the suspicion that consciously resisting and retraining our sexual desires will inevitably result in psychological harm, to the fear that assessing desires by political standards will lead to moralistic social policing.

Let us also consider what controlling or habituating sexual desire would mean for the new objects of desire. There is a danger that the message is something like this: ordinarily, I would find you too repulsive, plain, or downright unsexy to bother with - but, out of a generous sense of duty, I have trained myself to overcome my aversion or indifference to you. At the very least, there seems something patronising about that attitude. As Amia Srinivasan puts it, "no one really wants a mercy fuck, and certainly not from a racist or a transphobe". ${ }^{14}$ Given that it is characteristic of much modern sexuality for people to want to be desired for who they are as specific individuals, then attempts to rework desire on the grounds of impartial justice may be self-undermining, insofar as they produce something that falls short of what many people value about being sexually desired by others. ${ }^{15}$

Srinivasan aptly sums up many of the challenges facing us:

\footnotetext{
${ }^{13}$ Chu, 'On Liking Women', p. 59.

${ }^{14}$ Amia Srinivasan, 'Does Anyone Have the Right to Sex?', London Review of Books 40:6 (2018), pp. 5-10.

${ }^{15}$ Compare sexuality with friendship in this respect. See Chiara Cordelli, 'Distributive Justice and the Problem of Friendship', Political Studies 63 (2015), pp. 679-695, p. 685.
} 
The question, then, is how to dwell in the ambivalent place where we acknowledge that no one is obligated to desire anyone else, that no one has a right to be desired, but also that who is desired and who isn't is a political question, a question usually answered by more general patterns of domination and exclusion. ${ }^{16}$

Is it, then, possible to articulate a plausible philosophy of sexual desire that builds on this recognition of the political dimension of attraction? Can this be done in a way that also avoids the pitfalls identified of being psychologically harmful, moralistic, patronising, or selfundermining ${ }^{17}$

\section{II}

The category of structural injustice provides conceptual foundations for a compelling philosophy of sexual attraction. While ethicists such as Cahill have recognised that sexual desires are often "deeply implicated in structures of inequality", my aim is provide a more systematic elaboration of this insight that can support a political analysis and response to the problem. ${ }^{18}$ To this end, I shall outline the most influential account of structural injustice, which can be found in the work of Iris Marion Young, and then show how it can help us understand orectic injustice with respect to our sexual lives.

We can begin with Young's general characterisation of structural injustices, which she says arise from "vulnerabilities to domination and deprivation that some people experience due to social-structural processes." ${ }^{19}$ Her understanding of social structures is indebted to William Sewell, who tells us they "are constituted by mutually sustaining cultural schemas and sets of

\footnotetext{
${ }^{16}$ Srinivasan, 'Does Anyone Have the Right to Sex?'

17 For discussion of other potential objections to such a project, see John Danaher, 'A Defence of Sexual Inclusion', Social Theory and Practice 46:3 (2020), pp. 467-96.

${ }^{18}$ Cahill, 'Sexual Desire, Inequality, and the Possibility of Transformation', p. 284.

${ }^{19}$ Iris Marion Young, Responsibility for Justice (Oxford: Oxford University Press, 2011), p. 64.
} 
resources that empower and constrain social action and tend to be reproduced by that action." 20 She adds that these structures also encompass the "practico-inert" effects of previous sociallymediated human actions on the physical and cultural environment. ${ }^{21}$ More fully, Young takes social structures to be sets of cultural schemas, resources, and practico-inert environments which influence the constraints and opportunities of the occupants of different social positions. ${ }^{22}$ For instance, class, race, and gender act as positions within social structures in this way - widening some affordances while narrowing others. Thus, Young likens the effect of a social structure to a "channel" which guides and constrains the flow of people's actions. ${ }^{23}$

Structural injustice emerges when socio-structural processes "put large groups of persons under systematic threat of domination or deprivation of the means to develop and exercise their capacities," while enabling others to dominate or develop and exercise their own capacities. $^{24}$ What, then, are domination and capacity-deprivation? Domination consists in "institutional conditions which inhibit or prevent people from participating in determining their actions or the conditions of their actions". ${ }^{25}$ In other words, the dominated have little control over the social and political forces that shape their lives. Young adverts to Marilyn Frye's famous birdcage analogy for oppression to explain what she means by "social structures that inhibit the capacities of some people", whereby our opportunities to act can be delimited by the cumulative effects of multiple obstacles - each like individual wires that may be

\footnotetext{
${ }^{20}$ William Sewell, 'A Theory of Structure: Duality, Agency, and Transformation', American Journal of Sociology 98:1 (1992) pp. 1-29, p. 27; Young, Responsibility for Justice, p. 60.

${ }^{21}$ Young, Responsibility for Justice, pp. 53-4.

${ }^{22}$ Young, Responsibility for Justice, pp. 56-7. For an alternative account of social structure, see Sally Haslanger, 'What is a Social Practice?' Royal Institute of Philosophy Supplement 82 (2018), pp. 231-47 and 'What Is A (Social) Structural Explanation?’ Philosophical Studies 173:1 (2015), pp. 113-30.

${ }^{23}$ Young, Responsibility for Justice, p. 53.

${ }^{24}$ Young, Responsibility for Justice, p. 52.

${ }^{25}$ Iris Marion Young, Justice and the Politics of Difference (Princeton: Princeton University Press, 1990), p. 38. I read "institutional conditions" weakly here - taking them to refer to social structures in general.
} 
circumventable when taken alone but which together make a cage that prevents free action. ${ }^{26}$ In sum, for Young, structural injustice occurs when a set of cultural schemas, resources, and practico-inert environments render the occupants of a social position vulnerable to domination or capacity-deprivation while enabling others to dominate or command a wide range of opportunities. If sheer vulnerability to domination or capacity-deprivation in these ways is sufficient, then structural injustice becomes very widespread. While there are good reasons to care if non-domination and non-deprivation occurs on an insecure basis, for our purposes we can make do with a more conservative version of the formulation that holds that actual domination or capacity-deprivation are needed.

We began our inquiry into orectic injustice with the observation that online daters in some countries routinely avoid black women and Asian men, such that occupying these social positions will, other things being equal, make it more difficult to find a sexual partner. Furthermore, these findings suggest the possibility of a wider pattern of racialised sexual aversion, with troubling implications for the welfare and social standing of disdained groups. For instance, sociologists confirm that sexual attractiveness is an increasingly central factor in determining access to romantic relationships, and that such relationships are correlated with high levels of subjective wellbeing. ${ }^{27}$ But even beyond opportunities for sexual intimacy and romantic relationships, feelings of stigmatisation arising from being the object of racialised sexual aversion can undermine people's self-respect.

\footnotetext{
${ }^{26}$ Iris Marion Young, Inclusion and Democracy (Oxford: Oxford University Press, 2000), pp. 92-3; Iris Marion Young, 'Equality of Whom? Social Groups and Judgments of Injustice', Journal of Political Philosophy 9:1 (2001), pp.1-18, p. 10; Young, Responsibility for Justice, p. 55; Marilyn Frye, 'Oppression', The Politics of Reality: Essays in Feminist Theory (Freedom, CA: Crossing Press, 1993), pp. 1-16, pp. 4-5.

27 Eva Illouz, Why Love Hurts (Cambridge: Polity, 2012), p. 42; Claire Kamp Dush and Paul Amato, 'Consequences of Relationship Status and Quality for Subjective Well-Being', Journal of Social and Personal Relationships 22:5 (2005), pp. 607-27.
} 
Do such effects amount to domination or unequal capacity-distribution? Domination, so understood, obtains when people are prevented from participating in shaping the social conditions under which they act, such as the political authority to which they are subject and the informal rules that regulate social interactions with them. Systemic sexual aversions grounded in racialised preferences are often plausible candidates for such domination, especially when they disproportionately affect racial and ethnic minorities. For instance, Asian men often encounter cultural schemas which lead them to be read as effeminate and passive, which, when combined with heterosexual norms favouring a confident and active masculinity, results in diminished sexual desire for them on average. ${ }^{28}$ When these schemas and norms are imposed or sustained by members of majority groups, with little scope for the disadvantaged to shape, contest, or resignify how they are understood by others, then there is a danger of cultural domination.

Socio-structural processes driving racialised sexual aversion can also underpin capacity-deprivation. Consider the impact of relatively low levels of sexual desire for black women in certain contexts when compared to women of other racial groups. Some of the direct effects on the capacities of these women are obvious - namely, that ceteris paribus they will have less opportunities for sexual pleasure, intimacy, and romantic connection than others. But other effects are subtler and more closely aligned with the birdcage model of oppression, such as the relative loss of opportunities to form long-term relationships, which can bring economic costs associated with single-earner households, and so compound the economic

\footnotetext{
${ }^{28}$ Yen Ling Shek, 'Asian American Masculinity: A Review of the Literature', Journal of Men's Studies 14:3 (2006), pp. 379-91, pp. 383-6; Clara Wilkins, Joy Chan, Cheryl Kaiser, 'Racial Stereotypes and Interracial Attraction: Phenotypic Prototypicality and Perceived Attractiveness of Asians', Cultural Diversity and Ethnic Minority Psychology 17:4 (2011), pp. 427-431.
} 
marginalisation that black women disproportionately encounter from other sources. ${ }^{29}$ Indeed, even upwardly-mobile and college-educated black women in the U.S. face unequal and limited sexual and romantic options, owing to a confluence of "class-race-gender constraints", including attempts to consciously avoid negatively stereotyped behaviours commonly associated with poorer black women's sexuality. ${ }^{30}$

Domination and capacity-deprivation are not confined to racialised sexual aversion. The racial fetishism of yellow fever presents us with another example of a harmful hermeneutic schema which significantly shapes social interactions with Asian women but which largely escapes their control. Likewise, people with disabilities often rightly resent cultural conventions and legal apparatuses that reinforce their desexualisation, under conditions where they are denied sufficient social agency to fundamentally reframe how others see and treat them, and to thereby avoid some measure of domination. ${ }^{31}$ Yellow fever and the desexualisation of the disabled can also involve capacity-deprivation too. Consider the negative effects on self-esteem reported by those subjected to each of these phenomena, which can create obstacles to autonomous action that further constrict their effective room for manoeuvre beyond the already excessively narrow social roles often impressed upon them. ${ }^{32}$

\footnotetext{
${ }^{29}$ See Jacqueline Jones, Labor of Love, Labor of Sorrow (New York: Basic Books, 1985), pp. 325-6; Rose Brewer, 'Black Women in Poverty: Some Comments on Female-Headed Families', Signs: Journal of Women in Culture and Society 13:2 (1988), pp. 331-9. On the challenge of intersectionality with respect to sexual racism, see Sonu Bedi, Private Racism (Cambridge: Cambridge University Press, 2020), pp. 121-3.

${ }^{30}$ Averil Clarke, Inequalities of Love: College-Educated Black Women and the Barriers to Romance and Family (Durham, NC: Duke University Press, 2011), p. 15.

31 Richard Keller and Corrine Galgay, 'Microagressive Experiences of People with Disabilities', Microaggressions and Marginality: Manifestation, Dynamics, and Impact, ed. Derald Wing Sue (Hoboken, NJ: John Wiley \& Sons, 2010), pp. 241-268, pp. 260-1.

32 On autonomy and self-esteem, see Paul Benson, 'Feminist Intuitions and the Normative Substance of Autonomy', Personal Autonomy: New Essays on Personal Autonomy and its Role in Contemporary Moral Philosophy, ed. James Stacey Taylor (Cambridge: Cambridge University Press, 2005), pp. 124-42.
} 
Social structures which shape sexual preferences in ways that result in domination and capacity-deprivation can be of ethical concern. The awareness that we are reproducing preferences or social structures which disempower or harm others could prompt us to recognise a moral obligation to examine, evaluate, and alter our individual sexual comportment or social behaviour. For instance, someone strongly inclined to exclusively seek out Asian women as sexual partners, or even who reproduces stereotypical attitudes towards Asian women which treat them as particularly exotic or submissive, would be a plausible candidate for the bearer of a moral responsibility to change their ways.

We can consider and assess two ethical strategies which have been suggested for reshaping our sexual desires on an individual basis in this way. The first of these is Elizabeth Emens' appeal to ethical self-reflection. She suggests that people should engage in a kind of structured self-inquiry, where we ask, "What are the essential functions of the job of being my partner?"33 We then scrutinize our own replies to this question so that we can better understand why we tend to exclude some people from our pool of potential partners based on factors like race or disability. Emens says she hopes this will serve a "debiasing function by helping to contextualize these traits and to encourage more than a gut response based on the norms of intimate discrimination". ${ }^{34}$ The final stage of self-reflection is to ask whether there are accommodations we or others could make that would help someone we would otherwise exclude to instead fulfill our essential criteria. This line of thought is modelled on the requirement that much disability legislation imposes on employers to consider whether reasonable accommodations could be made for potential employees.

\footnotetext{
${ }^{33}$ Emens, 'Intimate Discrimination', p. 1360.

${ }^{34}$ Emens, 'Intimate Discrimination', p. 1362.
} 
The second strategy focuses not on individual self-reflection but individual rehabituation. ${ }^{35}$ Recall that Mitchell and Wells construct an analogy between preferences for food and sexual desires in order to point out that individuals can influence our desires over time by choosing to put themselves in environments which are likely to cultivate new attractions. Like persisting in eating familiar foods, which can begin to form new culinary desires, they reason that socializing with members of unfamiliar groups can make us more open to developing sexual and romantic desires for them. Mitchell and Wells consider the objection that forms of habituation like gay conversion therapy are ineffective and have disastrous results, but they suggest that both lived experience and empirical research on desire-formation with respect to race shows that success here is much more likely. ${ }^{36}$

There is, however, reason to be cautious here. While both self-reflection and rehabituation can have some effect on desire-formation, exhorting individuals to modify their own desires may be of limited effect. These individuals first need to be convinced there is a problem with their desires, with many likely to respond defensively to any suggestion there is a racial or ableist dimension to their own preferences. Furthermore, supposing people can be convinced, techniques like self-reflection and rehabituation may take us only so far in actually modifying our sexual desires, since they go against the grain of the social and psychological forces which helped produce the original desires, which will often remain intact - even if, like Mitchell, Wells, and Cahill recommend, we find some opportunities for placing ourselves in new social contexts.

Other solutions depend less on the good will and initiative of individuals diligently working to remold their own sexual desires but rather deeper structural interventions in the

\footnotetext{
${ }^{35}$ These are not mutually exclusive strategies: Cahill recommends both self-reflection and rehabituation. Cahill, 'Sexual Desire, Inequality, and the Possibility of Transformation', p. 297.

${ }^{36}$ Mitchell and Wells, 'Race, Romantic Attraction, and Dating', p. 951.
} 
social and physical environments within which our desires are formed. Some of these solutions are directed towards the infrastructure of dating - for instance, Sonu Bedi has suggested measures like removing racial search functions of dating apps. ${ }^{37}$ There might, however, be some legitimate uses of these functions, such as the desire of members of racial minorities to find a partner from a group who is less likely to subject them to racial microaggressions or fetishization. Thus, Robinson has claimed, "a person of color who has experienced persistent racial conflict in romantic relationships might legitimately adopt a preference for people of his or her own race". ${ }^{38}$ In a similar vein, Ian Ayers and Jennifer Gerarda Brown suggest there are grounds to adopt an "antisubordination norm" in evaluating sexual preferences, which allows that there is "stronger moral justification for a black homoracial orientation than a white homoracial one". ${ }^{39}$ Therefore, a blanket ban on racial searching in online dating may be too hasty.

Nevertheless, there is good reason to consider other aspects of the architecture of online dating, such as the assumptions underlying the design of matching algorithms. For instance, the dating app CoffeeMeetsBagel was found to show users a disproportionate number of potential partners of their own ethnicity, even if those users had explicitly stated that they had no ethnic preference. The company defended itself by arguing that the revealed preference of its users - whatever their stated preference - showed they did favour homogamous matches. ${ }^{40}$ However, we do not have to take a predicted revealed preference as the ultimate standard in design decisions. In this spirit, and noting the fluidity of our intimate desires in response to

\footnotetext{
${ }^{37}$ Bedi, 'Sexual Racism', p. 1007.

${ }^{38}$ Robinson, ‘Structural Dimensions of Romantic Preferences’, p. 2793.

${ }^{39}$ Ian Ayers and Jennifer Gerarda Brown, Straightforward: How to Mobilize Heterosexual Support for Gay Rights (Princeton: Princeton University Press, 2005), p. 35.

${ }^{40}$ Katie Notopoulos, 'The Dating App That Knows You Secretly Aren't Into Guys From Other Races', Buzzfeed (2016), available: https://www.buzzfeednews.com/article/katienotopoulos/coffee-meets-bagel-racial-preferences [accessed: August 2019].
} 
unanticipated options, Hutson et al have argued that rather than "relying on assumptions about subconscious preferences, [...] intimate platforms should instead encourage accidents and exploration with the goal of actively counteracting bias". ${ }^{41}$

We might worry that such design choices would deprive users of autonomy. However, there is no neutral matching mechanism free from assumptions about which other users a person should encounter most prominently. Even a totally random presentation of potential daters favours an open-minded comportment - indeed, one that will be frustratingly undiscriminating for most users, who will want to narrow down their options to a manageable but viable selection. Therefore, so long as users are not being deceived about the matching process, there is legitimate scope to select a default algorithm that promotes rather than frustrates social justice.

Further structural solutions target the legal background to desire formation. Emens proposes lifting formal civil or criminal restrictions on who can have sex or marry, such as excessively strict competency requirements imposed on consent to sex for people with intellectual disabilities. ${ }^{42}$ She also thinks we should design institutions and urban spaces with an eye to "propinquity" - that is, who does and does not meet on a regular basis. ${ }^{43}$ When propinquity considerations are designed into physical and social environments, then this shifts the burden of seeking out atypical interactions away from the individual (as in individual-led reflection and rehabituation), while still leaving some scope to them with respect to the nature and intensity of their social interactions with others.

\footnotetext{
41 Jevan Hutson, Jessie Taft, Solon Barocas, and Karen Levy, 'Debiasing Desire: Addressing Bias \& Discrimination on Intimate Platforms', Proceedings of the ACM on Human-Computer Interaction 2 (2018), no. 73 , p. 9 .

42 Emens, 'Intimate Discrimination', p. 1390.

${ }^{43}$ Emens, 'Intimate Discrimination', p. 1367.
} 
These structural interventions focus on the background structures within which people form desires. This avoids the problem of individuals having to consciously reshape their own desires in ways that might be experienced as patronising or depersonalising by the objects of those desires. While it is possible that beneficiaries of structural interventions will still feel condescended to, such feelings are likely to be less intense than interpersonal angst about whether a particular sexual or romantic partner is motivated primarily by a sense of justice rather than immediate attraction. Furthermore, structural interventions do not involve a requirement to undertake a deeply personal project of self-transformation, with a potentially psychologically demanding attempt to break oneself out of longstanding patterns of sexual desire. Instead, this work is partially outsourced to the practico-inert environments we find ourselves in.

The principally structural response recommended here goes beyond the recognition of structural determinants of sexual desire that we find in theorists like Cahill. ${ }^{44}$ It also matters how we respond to this insight. Cahill's focus is an ethical strategy of resisting or mitigating the effects of pernicious social structures through self-reflection and individual rehabituation, rather than a political strategy of transforming these structures. As we shall see shortly, this political framework can also give us a sense of who has the strongest political responsibilities to undertake this collective work of transformation. However, it is worth emphasising that we are not always faced with a sharp choice between individual and structural remedies: benign forms of individual rehabituation or self-reflection - such as efforts to unpick one's own racial or ableist stereotyping through self-education - can be combined with wider socio-structural

\footnotetext{
${ }^{44}$ Cahill, 'Sexual Desire, Inequality, and the Possibility of Transformation', p. 284.
} 
change. The resulting approach is likely to be more effective than either strategy pursued alone. $^{45}$

\section{IV}

What can justify moving beyond individual ethical self-reform to mandate these broader structural interventions that reorder the physical, legal, and social environment within which sexual desires are formed? Young's account of structural injustice provides us with the resources for identifying explicitly political responsibilities to rectify such injustice irrespective of any ethical duties it generates. This political rather than primarily ethical conception of structural injustice can provide the initial impetus for a more ambitious project of structural transformation of sexual desire - although, as we shall see, important questions as to the limits of political action in matters of sexuality still need to be addressed.

No single individual is the sole cause of the structural conditions under which they or others find themselves, and isolated individuals only rarely have the power to radically reshape these structures. So, on what basis can we identify whether someone has a political responsibility to enact changes to the background structures which shape sexual desire? The state might seem to be most appropriate bearer of responsibility, and able to make some headway here - for instance, spearheading attempts to reform legislation that compounds orectic injustice. But many of the social structures that determine who and how we desire are more informal and cultural than those mandated in explicit legislation and policy.

Young's model can offer a solution here, insofar as it provides us with conceptual resources for assigning a wider political responsibility to correct structural injustice. In

\footnotetext{
${ }^{45}$ I do not mean to exclude the possibility that there may be other ways of avoiding orectic structural injustice than influencing our own or other people's desires - such as bolstering their capacities, social power, or social standing in other respects. However, this is not a strategy I shall investigate here.
} 
particular, Young identifies four parameters for thinking through the distribution of political responsibilities: power, privilege, interest, and collective ability. ${ }^{46}$ The greater the power of an agent over the relevant structures, the more their relative privilege, the closer aligned their interests are with bringing about justice, and the deeper their ability to bring about change collectively with other individuals and groups, then the more political responsibility they are attributed. Conversely, those lacking power and privilege are accorded less responsibility for combatting structural injustice.

Consider how these parameters would shape attributions of responsibility in the context of structural injustice arising from the desexualisation of the disabled. Those with greater powers over the relevant cultural norms, environmental factors, and legal barriers to opportunities for sexual intimacy for people with disabilities should recognise a greater political responsibility: the screenwriter who has the opportunity to sensitively depict the sexual lives of people with disabilities, the urban planner able to address propinquity by making provision for accessible workplaces and public amenities, the legislator debating mental health and mental capacity bills, and so on. ${ }^{47}$ Those with more collective leverage will have a larger responsibility too, such as those plugged into disability rights groups, political parties, and other organisations within civil society, or who have the capacity to organise large-scale political and social action to address or educate people about the problem of desexualisation, including pressuring government, media, healthcare providers, social services, and workplaces into action. Likewise, people with a greater interest in ending desexualisation are more appropriate bearers of the political responsibility for combatting it, such that movements in this

\footnotetext{
46 Young, Responsibility for Justice, p. 144-7.

${ }^{47}$ Similar considerations will apply with respect to race, such as to the author who can avoid gratuitous Orientalism in their depiction of Asian women, the local government official who can push against racial ghettoisation in their zoning decisions, or the computer programmer able to redesign dating platforms without a bias towards homogamy.
} 
area are led by disabled people themselves who are at the sharp end of a society whose members are unable to comprehend how they could make a desirable sexual partner. So too, the relative level of privilege of the agents involved has a bearing, with the richer, educated, healthier, and less oppressed being expected to absorb more of the costs of pushing for desexualisation than, say, those people with disabilities who have to bear heavy burdens elsewhere in their lives due to poverty or discrimination.

Young's move from individual moral responsibility to political responsibility also helps to shift the focus from individual blame, which might end up being moralising and shaming, and towards a collective and cooperative response to the problem of orectic injustice. Furthermore, it does not rely on us making potentially invidious, irrelevant, or unproductive ethical assessments of the beliefs or character of the agents in question. For example, Raja Halwani's qualified defence of racial sexual preferences tries to establish that the possessors of such preferences need not be racist, in the sense of holding racist beliefs or attitudes. ${ }^{48}$ From the perspective of structural injustice, this kind of inquiry is beside the point. We do not care so much what goes on in people's heads for its own sake, but rather what contribution their sexual preferences and associated behaviour makes to systemically reproducing inequality and its effects on the social world of others. This shift in perspective is similar to the one pursued by Kate Manne in her recent analysis of misogyny, which proposes that we pay less attention to whether an individual has a feeling of hatred towards women deep in their hearts, but rather concern ourselves with whether women confront hostile social systems and environments which enforce patriarchal relationships. ${ }^{49}$

\footnotetext{
${ }^{48}$ Halwani, 'Racial Sexual Desires'.

${ }^{49}$ Kate Manne, Down Girl: The Logic of Misogyny (Oxford: Oxford University Press, 2017).
} 
The politicisation of orectic injustice might seem troubling, however, when compared to more modest ethical projects of individual self-scrutiny and rehabituation of sexual desire. Political intervention in the regulation of sexual relationships has a grim history: eugenics, forced sterilization, anti-miscegenation laws, punishment of fornication, criminalization of homosexuality, and many more disconcerting cases of state intrusion into people's sexual lives. An understandable reaction to this history would be to adopt a 'sexual liberalism of fear': the guarantee or strong presumption by the state of non-intervention with respect to the noncoerced sexual desires and choices of its citizens, informed by a well-evidenced historical pessimism about the meagre benefits and outsized harms that interventionist political policies in this area have had. ${ }^{50}$ When stacked against this bleak history, then recommendations for ethically-motivated attempts to rework one's own sexual desires appear more attractive, insofar as the locus of control remains with the desiring individual rather than a potentially overreaching political collective.

Yet, there are reasons to be less sceptical of a political framing. Firstly, a political diagnosis and remedy to orectic injustice need not rely on the clunking fist of the state to force people to change their ways. We have seen that the conception of political responsibility driving Young's understanding of structural injustice is not statist: all individuals and groups with the relevant power, privilege, interest, or collective ability are responsible for acting cooperatively to redress the injustice. Nor is state action typically the most appropriate vehicle for achieving orectic justice - for instance, individuals, civil society groups, and non-state institutions took centre-stage when we considered desexualisation and disability. Politics is

\footnotetext{
${ }^{50}$ See Judith N. Shklar, 'The Liberalism of Fear', Liberalism and the Moral Life, ed. Nancy L. Rosenblum (Cambridge, MA: Harvard University Press), pp. 21-38 and Srinivasan, 'Does Anyone Have the Right to Sex?'
} 
about far more than the state and its coercive power: it extends to many forms of collective determination of the conditions under which we live together.

Are there, nevertheless, any principled limits on state action in pursuing orectic justice? Respect for personal autonomy, including sexual autonomy, should preclude states from punishing those with racial or ableist sexual aversions or fetishes, or singling them out for mandatory education. Other direct forms of coercion, such as forced socialisation or involuntary pharmacological interventions to reshape sexual desire ought to be ruled out on similar grounds. Likewise, a presumption in favour of worker control over private economic enterprises would provide a reason for the state to simply recommend rather than mandate certain infrastructures on dating sites and apps. Instead, the state should concentrate on transforming more diffuse socio-structural influences on desire-formation - such as in urban design, general anti-discrimination legislation, sexual education in school curricula, disability law reform, and closing racial wealth gaps.

The state is not the only political force that might be overzealous in opposing orectic injustice. Consider Mill's wariness towards "the tendency of society to impose, by other means than civil penalties, its own ideas and practices as rules of conduct on those who dissent from them". ${ }^{51}$ For instance, does a political responsibility to remedy orectic injustice recommend a collective social shaming or shunning of people for their sexual aversions or fixations? No. The structural focus of my account of orectic injustice is intended to refocus our attention away from questions of people's individual moral liability and towards the environmental pressures that contributed to the formation of their sexual preferences. Of course, individual moral evaluation of oneself and others with respect to orectic injustice is still permissible and will often prompt some degree of effective self-reflection and rehabituation. But pushing beyond

\footnotetext{
${ }^{51}$ John Stuart Mill, On Liberty and Other Writings (Cambridge: Cambridge University Press, 1989), p. 8.
} 
this to encourage a culture of moralistic denunciation is not an attractive way of discharging a political responsibility to combat unjust patterns of sexual attraction, especially once we have acknowledged that people's individual agency with respect to desire is often conditioned by social structures over which they have limited influence.

Our account faces a final objection that arises not from the fear that remedies to structural orectic injustice are overreaching but that such injustice is nevertheless overdiagnosed. Consider people who are undesired merely because they are regarded as ugly or otherwise aesthetically unappealing. Does it really matter from the standpoint of justice that beautiful Alcibiades quickens more hearts than snub-nosed Socrates? We might recognise general ethical and political duties not to needlessly socially exclude and stigmatise those found less aesthetically appealing in our everyday lives. ${ }^{52}$ Similarly, we may try to take a less caustic or inflexible attitude towards such people in cultivating our own sexual desires. But accounts which imply that the merely aesthetically disfavoured are victims of outright political injustice in their sexual lives are likely to strike many of us as excessively lax - either trivialising injustice or else producing too many false positives. ${ }^{53}$ I shall recommend a relational egalitarian response to this challenge.

52 On aesthetic discrimination in general, see Duane Willard, 'Aesthetic Discrimination Against Persons', Dialogue: Canadian Philosophical Review 16 (1977), pp. 676-92; Alan Soble, 'Physical Attractiveness and Unfair Discrimination', International Journal of Applied Philosophy 1 (1982), pp. 37-64; Francesca Minerva, 'The Invisible Discrimination Before Our Eyes: A Bioethical Analysis', Bioethics 31:3 (2017), pp. 180-9.

${ }^{53}$ For discussion of related objections in this vein, see Bedi, 'Sexual Racism', pp. 1003-5; Zheng, 'Why Yellow Fever Isn't Flattering', pp. 412-4; Raja Halwani, 'Racial Sexual Desires', The Philosophy of Sex: Contemporary Readings, ed. Raja Halwani, Alan Soble, Sarah Hoffman, and Jacob Held (London: Rowman and Littlefield, 2017), pp. 181-99; Carina Fourie, 'Wrongful Private Discrimination and the Egalitarian Ethos', The Routledge Handbook of the Ethics of Discrimination, ed. Kasper Lippert-Rasmussen (Abingdon: Routledge, 2018), pp. 42132 , p. 428. 
Political injustice is not simply any social disadvantage or unfairness. Elizabeth Anderson famously argues "the proper aim of egalitarian justice" is to "end oppression" and "create a community in which people stand in relations of equality to others" rather than to "ensure that everyone gets what they morally deserve". ${ }^{54}$ Seen from this relational egalitarian perspective, we should identify structural injustice only when social structures bring about domination or capacity-deprivation that constitutes or compounds oppression or fundamentally unequal social status.

Sexual aversion or fetishism encountered by racially marginalised groups often arises from or coexists with racialised othering, stereotyping, discrimination, segregation, microaggression, economic exclusion, cultural denigration, or even outright violence. Likewise, desexualisation of the disabled is both fuelled by and reproduces widespread ableism. When this happens, there are typically strong grounds for supposing that domination or capacity-deprivation resulting from such aversions, fetishes, and desexualisation will reinforce oppressive social relationships, with sexual attitudes towards racial minorities and people with disabilities bolstering their effective status as second-class citizens.

Yet, orectic structural injustice need not always be a dimension of a wider social injustice. If socio-structurally-mediated sexual aversion to the aesthetically unappealing was so pronounced and burdensome that the domination or capacity-deprivation they faced as a result made it unreasonably challenging for them to live with comparable dignity to others in society, then this would be a pure orectic structural injustice. More plausibly, this injustice would obtain when our cultural schemas or practico-inert environments are responsible for obesity, ugliness, plainness, scarring, or disfigurement being the object of such intense sexual

\footnotetext{
${ }^{54}$ Anderson, 'What Is the Point of Equality?', pp. 288-9.
} 
aversion that its targets were left without capacities for sexual intimacy or self-respect that would allow them to live as people of equal social status to others, despite not being oppressed or socially disadvantaged in other respects. Under these conditions, there would be a political responsibility on those with the greatest power, privilege, interest, and joint ability to collectively reimagine and reshape social structures in order to foster more egalitarian social relationships with the aesthetically unappealing. That could include changes to shaming linguistic habits, derogatory interpersonal norms, modes of media representation, artistic conventions, or dating infrastructure. But it would not require us to be totally indifferent to how people look in our individual sexual preferences.

\section{VI}

My aim has been to demonstrate that there are injustices in the distribution and character of our sexual desires and that we can be held responsible for correcting these injustices. Among the central examples of orectic injustice canvassed have been those of racialised sexual desire: whether the racial aversion confronted by many black women and Asian men, the depersonalising fetishism of yellow fever encountered by Asian women, or the racialised sex roles often foisted upon black men. But we have considered cases such as the desexualisation of the disabled too, which also involve subjection to dominating power and social systems which result in highly unequal distributions of capacities. In developing an analysis of these phenomena, I have built upon the general conception of structural injustice found in Iris Marion Young's writings - showing how it can used to diagnose those socio-structural processes shaping the formation of desire which can compound systemic domination and capacitydeprivation, as well as supporting attributions of political responsibility to alter these structures. 
We saw that when orectic structural injustices arise, this does not license a moralistic condemnation of individual wrongdoing, which is intended to shame or compel wrongdoers into changing their ways. The structural account of orectic injustice pursued here instead directs us to ways we can intervene in wider social structures rather than singling out specific offenders. These structural solutions include making changes to the architecture of online dating, removing unnecessary legal obstacles to sexual intimacy, and ensuring that institutional and urban design pays sufficient attention to social mixing. Structural interventions do not preclude individual ethical projects of self-transformation and rehabituation of desire, but they avoid the potentially psychologically burdensome and self-undermining aspects of these approaches - partially outsourcing the work of preference-reformation to the practico-inert environments we find ourselves in.

The account also provides a plausible model for assigning political responsibilities for implementing these structural changes, which will fall heavier on those with greater power and privilege. In doing so, it emphasises the importance of non-statist political interventions, while prohibiting remedies to orectic injustice that rely on highly coercive and punitive state action or collective social shaming or shunning. Finally, we have seen how a relational egalitarian approach to orectic justice can provide a measured response to the aesthetically unappealing, which allows that they are subject to orectic structural injustice only when exposed to oppression or second-class citizenship. Thus, in conclusion, there are compelling reasons to approach the social philosophy of sexual desire in terms of the political category of structural injustice. 
An early version of the paper was presented at the Society for Applied Philosophy's annual conference in Cardiff, and I would like to thank Jessica Begon, Luke Brunning, Rich Healey, Natasha McKeever, Mari Mikkola, and Marie Moran, among others, for their comments on that occasion, as well as Alison Toop for chairing the session. I also would like to acknowledge the comments of three anonymous referees for the journal and the efforts of the editorial staff.

\section{References}

Anderson, Elizabeth. 'What Is the Point of Equality?', Ethics 109:2 (1999), pp. 287-337.

Ayers, Ian and Jennifer Gerarda Brown. Straightforward: How to Mobilize Heterosexual Support for Gay Rights (Princeton: Princeton University Press, 2005).

Bedi, Sonu. 'Sexual Racism: Intimacy as a Matter of Justice', The Journal of Politics 77:4 (2015), pp. 998-1011.

Bedi, Sonu. Private Racism (Cambridge: Cambridge University Press, 2020).

Benson, Paul. 'Feminist Intuitions and the Normative Substance of Autonomy', Personal Autonomy: New Essays on Personal Autonomy and its Role in Contemporary Moral Philosophy, ed. James Stacey Taylor (Cambridge: Cambridge University Press, 2005), pp. 12442.

Brewer, Rose. 'Black Women in Poverty: Some Comments on Female-Headed Families', Signs: Journal of Women in Culture and Society 13:2 (1988), pp. 331-9.

Cahill, Ann J. 'Sexual Desire, Inequality, and the Possibility of Transformation', Body Aesthetics, ed. Sherri Irvin (Oxford: Oxford University Press, 2016), pp. 281-98.

Chu, Andrea Long. 'On Liking Women', n + 130 (2018), pp. 47-62. 
Clarke, Averil. Inequalities of Love: College-Educated Black Women and the Barriers to Romance and Family (Durham, NC: Duke University Press, 2011).

Cordelli, Chiara. 'Distributive Justice and the Problem of Friendship', Political Studies 63 (2015), pp. 679-695.

Danaher, John. 'A Defence of Sexual Inclusion', Social Theory and Practice 46:3 (2020), pp. 467-96.

Dawson, Juno. “I Can't Be A 24-Hour Sexual Fantasy": Juno Dawson on Dating as a Trans Woman', The Guardian (Friday $19^{\text {th }}$ May 2017), available: https://www.theguardian.com/society/2017/may/19/juno-dawson-cant-be-24-hour-sexualfantasy-dating-trans-woman [accessed: August 2019].

Dickinson, Emily. The Letters of Emily Dickinson, vol 2, eds. Thomas Johnson and Theodora Ward (Cambridge, MA: Harvard University Press, 1958).

Dush Claire Kamp and Paul Amato. 'Consequences of Relationship Status and Quality for Subjective Well-Being', Journal of Social and Personal Relationships 22:5 (2005), pp. $607-$ 27.

Emens, Elizabeth. 'Intimate Discrimination: The State's Role in the Accidents of Sex and Love', Harvard Law Review 122:1307 (2009), pp. 1308-1402.

Fourie, Carina. 'Wrongful Private Discrimination and the Egalitarian Ethos', The Routledge Handbook of the Ethics of Discrimination, ed. Kasper Lippert-Rasmussen (Abingdon: Routledge, 2018), pp. 421-32.

Frye, Marilyn. 'Oppression', The Politics of Reality: Essays in Feminist Theory (Freedom, CA: Crossing Press, 1993), pp. 1-16.

Gomez, Selena. 'The Heart Wants What It Wants', For You (Hollywood Records, 2014). 
Haldeman, Douglas. 'The Practice and Ethics of Sexual Orientation Conversion Therapy', Journal of Consulting and Clinical Psychology 62:2 (1994), pp. 221-227.

Halwani, Raja. 'Racial Sexual Desires', The Philosophy of Sex: Contemporary Readings, ed. Raja Halwani, Alan Soble, Sarah Hoffman, and Jacob Held (London: Rowman and Littlefield, 2017), pp. 181-99.

Haslanger, Sally. 'What is a Social Practice?' Royal Institute of Philosophy Supplement 82 (2018), pp. 231-47

'What Is A (Social) Structural Explanation?' Philosophical Studies 173:1 (2015), pp. 113-30.

Hutson, Jevan, Jessie Taft, Solon Barocas, and Karen Levy, 'Debiasing Desire: Addressing Bias \& Discrimination on Intimate Platforms', Proceedings of the ACM on Human-Computer Interaction 2 (2018), no. 73.

Illouz, Eva. Why Love Hurts (Cambridge: Polity, 2012).

Jones, Jacqueline. Labor of Love, Labor of Sorrow (New York: Basic Books, 1985).

Keller, Richard and Corrine Galgay, 'Microagressive Experiences of People with Disabilities', Microaggressions and Marginality: Manifestation, Dynamics, and Impact, ed. Derald Wing Sue (Hoboken, NJ: John Wiley \& Sons, 2010), pp. 241-268.

Klumbyte, Goda and Katrine Smiet, 'Bodies Like Our Own? The Dynamics of Distance and Closeness in Online Fat Porn', Fat Sex: New Directions in Theory and Activism, Helen Hester and Caroline Walters (Farnham: Ashgate, 2015), pp. 133-54.

Lazenby, Hugh and Paul Butterfield. 'Discrimination and the Personal Sphere', The Routledge Handbook of the Ethics of Discrimination, ed. Kasper Lippert-Rasmussen (Abingdon: Routledge, 2018), pp. 369-378. 
Manne, Kate. Down Girl: The Logic of Misogyny (Oxford: Oxford University Press, 2017).

Mill, John Stuart. Collected Works of John Stuart Mill, vol. 26-27, ed. John Robson, (London: Routledge, 1988).

_ On Liberty and Other Writings (Cambridge: Cambridge University Press, 1989)

Minerva, Francesca. 'The Invisible Discrimination Before Our Eyes: A Bioethical Analysis', Bioethics 31:3 (2017), pp. 180-9.

Mitchell, Megan and Mark Wells. 'Race, Romantic Attraction, and Dating', Ethical Theory and Moral Practice 21:4 (2018), pp. 945-61.

Notopoulos, Katie. 'The Dating App That Knows You Secretly Aren't Into Guys From Other Races', Buzzfeed (2016), available:

https://www.buzzfeednews.com/article/katienotopoulos/coffee-meets-bagel-racialpreferences [accessed: August 2019].

Nussbaum, Martha. 'Objectification', Philosophy \& Public Affairs 24 (1995), pp. 249-91.

OkCupid, 'Race and Attraction, 2009-2014', The OkCupid Blog, available: https://theblog.okcupid.com/race-and-attraction-2009-2014-107dcbb4f060 [accessed August 2019].

Robinson, Russell. 'Structural Dimensions of Romantic Preferences', Fordham Law Review 76 (2008), pp. 2787-819.

Salska, Irmina, David A. Frederick, Boguslaw Pawlowski, Andrew H. Reilly, Kelsey T. Laird, Nancy A. Rudd. 'Conditional Mate Preferences: Factors Influencing Preferences for Height', Personality and Individual Differences 44:1 (2008), pp. 203-215.

Sewell, William. 'A Theory of Structure: Duality, Agency, and Transformation', American Journal of Sociology 98:1 (1992) pp. 1-29. 
Shek, Yen Ling. 'Asian American Masculinity: A Review of the Literature', Journal of Men's Studies 14:3 (2006), pp. 379-91, pp. 383-6.

Shklar, Judith N. 'The Liberalism of Fear', Liberalism and the Moral Life, ed. Nancy L. Rosenblum (Cambridge, MA: Harvard University Press), pp. 21-38.

Soble, Alan. 'Physical Attractiveness and Unfair Discrimination', International Journal of Applied Philosophy 1 (1982), pp. 37-64.

Srinivasan, Amia. 'Does Anyone Have the Right to Sex?', London Review of Books 40:6 (2018), pp. 5-10.

Wilkins, Clara, Joy Chan, and Cheryl Kaiser. 'Racial Stereotypes and Interracial Attraction: Phenotypic Prototypicality and Perceived Attractiveness of Asians', Cultural Diversity and Ethnic Minority Psychology 17:4 (2011), pp. 427-431.

Willard, Duane. 'Aesthetic Discrimination Against Persons', Dialogue: Canadian Philosophical Review 16 (1977), pp. 676-92.

Young, Iris Marion. Justice and the Politics of Difference (Princeton: Princeton University Press, 1990).

_ Inclusion and Democracy (Oxford: Oxford University Press, 2000), pp. 92-3.

_ 'Equality of Whom? Social Groups and Judgments of Injustice', Journal of Political Philosophy 9:1 (2001), pp. 1-18.

— Responsibility for Justice (Oxford: Oxford University Press, 2011).

Zheng, Robin. 'Why Yellow Fever Isn't Flattering: A Case Against Racial Fetishes', Journal of the American Philosophical Association 2:3 (2016), pp. 400-19. 


\section{Author Biography}

Tom O'Shea is a Senior Lecturer in Philosophy at the University of Roehampton. They research topics in moral, social, and political philosophy, especially those related to human freedom. Some of the journals where Tom's research has been published include Political Theory, European Journal of Philosophy, Philosophical Topics, and the Journal of Moral Philosophy. Their recent work focuses on the radical republican tradition and develops a socialist republicanism. 